\begin{tabular}{|c|c|c|}
\hline BENTHAM OPEN & $\begin{array}{c}\text { The Open Conference Proceedings } \\
\text { Journal }\end{array}$ & edings \\
\hline CrossMark & Content list available at: www.benthamopen.com/TOPROCJ/ & 4: \\
\hline & DOI: $10.2174 / 2210289201607010001$ & \\
\hline
\end{tabular}

\title{
Effects of Oleuropein and Peracetic Acid as Sanitizing Agents for Inactivation of Listeria monocytogenes Biofilms
}

\author{
Laura C. C. Dominciano ${ }^{1}$, Sarah H. I. Lee ${ }^{1}$, Carlos H. Corassin ${ }^{1}$, Elaine C. P. Martinis ${ }^{2}$ and Carlos
} A. F. Oliveira ${ }^{*}, 1$

${ }^{1}$ Department of Food Engineering, Faculty of Animal Science and Food Engineering, University of São Paulo, Pirassununga, SP, Brazil

${ }^{2}$ College of Pharmaceutical Sciences, University of São Paulo, Ribeirão Preto, SP, Brazil

\begin{abstract}
The development of more efficient sanitizers for reducing the biofilm produced by pathogenic bacteria is of great importance, especially in the food industry. The aim of this study was to conduct a preliminary evaluation of the efficiency of oleuropein (OLE), extracted from olive leaves, and peracetic acid (PAA), alone or in combination, to inactivate biofilms formed by a strong biofilm-producer strain of Listeria monocytogenes (ATCC 7644). A disk diffusion method was also used to assess the susceptibility of the ATCC 7644 strain cells to OLE and/or PAA. Triplicate biofilm assays were prepared on stainless steel coupons $\left(1 \mathrm{x} 1 \mathrm{~cm}^{2}\right)$ during $48 \mathrm{~h}$ without stirring. After incubation, the stainless steel was washed $(\mathrm{NaCl} 0.85 \%)$ and immersed in solutions of OLE $(5.0 \mathrm{mg} / \mathrm{mL})$ and/or PAA $(2.0 \%)$ for $1 \mathrm{~min}$. After 1-min treatment, the disinfectant solutions were removed from the tube. Two $\mathrm{mL}$ of sodium thiosulfate $0.1 \mathrm{M}$ was placed in the tube to stop reaction. The inactivation of biofilms was assessed by confocal laser scanning microscopy. L. monocytogenes cells tested in the disk diffusion method was not susceptible to OLE (inhibition zone (IZ) = $6 \mathrm{~mm}$ ), although its susceptibility was intermediate for PAA $(\mathrm{IZ}=8.67 \mathrm{~mm})$ and higher for PAA+OLE $(\mathrm{IZ}=14 \mathrm{~mm})$. Compared with PAA, OLE alone in contact with biofilms had also lower bactericidal activity on the biofilms. However, the treatment of OLE in combination with PAA resulted in greater inactivation of $L$. monocytogenes cells in biofilms. Results indicate a potential application of OLE for enhancing the bactericidal effect of PAA against L. monocytogenes biofilms, although further studies are necessary to understand the mechanisms of action of OLE in combination with commercial chemical sanitizers.
\end{abstract}

Keywords: L. monocytogenes, microbial biofilms, organic sanitizers, oleuropein, peracetic acid.

\section{INTRODUCTION}

Listeria monocytogenes is a Gram-positive rod-shaped, motile and ubiquitous foodborne pathogen with worldwide distribution. L. monocytogenes cells are tolerant to high salt concentration, can grow in a temperature range of 2.5 to $44^{\circ} \mathrm{C}$ and optimum $\mathrm{pH}$ from 6.0 to 8.0 [1], and have the ability to produce biofilms on different non-food contact and food contact surfaces, such as glass, stainless steel and rubber [2]. Biofilms of L. monocytogenes are difficult to remove, and can persist for long periods in the processing environment even after regular cleaning and sanitation procedures [3]. Biofilms of L. monocytogenes can constitute a protective barrier against detergents and sanitizers, being able to neutralize them because of the presence of complex extracellular polymer substances (EPS) [4]. The EPS leads to formation of a three dimensional gel-like network that involves the bacterial cells, and protects them from the antimicrobial action of chemical compounds [5]. Biofilms also provide friendly environmental conditions for the development of microbial resistance [6]. Considering those problems, there is a need for the development of strategies that could prevent the formation of bacterial biofilms or eliminate them from surfaces, especially in the food industry.

Peracetic acid (PAA) is an antimicrobial agent with oxidation capacity, which decomposes into safe products and is normally used at concentrations of $2-15 \%(\mathrm{v} / \mathrm{v})$. Its decomposition produces hydroxyls radical which subsequently

\footnotetext{
* Address correspondence to this author at the Department of Food Engineering, Faculty of Animal Sciences and Food Engineering, University of São Paulo, CEP: 13635-900, Pirassununga, SP, Brazil; Tels: +5519-3565-4173, +5519-3565-4284; Email: carlosaf@usp.br
} 
attack the cell components being one of the most used disinfectants in the food industry [7]. However, PAA has low storage stability, and it is incompatible with acids, alkaline concentrates, iron, copper, aluminum and natural and synthetic rubbers [6]. Oleuropein (OLE) is a phenolic compound extracted from olive leaves with antimicrobial activity against several types of virus, bacteria, fungi and other parasites [8,9]. Previous studies have demonstrated in vitro antimicrobial activity of olive oils on L. monocytogenes and Staphylococcus aureus, among other species [10], and several species of enterobacteria [11], as well as inhibitory effects of OLE against $S$. aureus and Salmonella species [12]. However, there is no previous information on the effectiveness of OLE alone or in combination with other chemical sanitizers on biofilms formed by foodborne pathogens. The objective of this study was to conduct a preliminary evaluation of the efficiency of OLE, alone or in combination with PAA, to inactivate biofilms formed by a strong biofilm-producer strain of L. monocytogenes on stainless steel.

\section{MATERIALS AND METHODS}

A L. monocytogenes strain (American Type Culture Collection, ATCC 7644) with strong ability to produce biofilms [13] was used in the experiment. The strain was previously suspended in Brain Heart Infusion broth (BHI) (Merck, Germany) with glycerol (Synth, Brazil) $15 \%$ (v/v), which was stored at $-80^{\circ} \mathrm{C}$. The bacterial working suspension was prepared by adding $15 \mu \mathrm{L}$ of the stock suspension to $5 \mathrm{~mL}$ of $\mathrm{BHI}$. The tube was incubated at $30^{\circ} \mathrm{C}$ for $24 \mathrm{~h}$, vortexed and finally adjusted with BHI until reaching 0.5 in the MacFarland scale (approximately $10^{8}$ cells $/ \mathrm{mL}$ ).

OLE (500 mg, purity: >80\%) was purchased from Sigma-Aldrich (Saint Louis, MO) and diluted in $10 \mathrm{~mL}$ of sterilized water (final concentration: $5.0 \mathrm{mg} / \mathrm{mL}$ ). A commercially available solution of PAA (Dinamica, São Paulo, Brazil) containing $2.0 \%(\mathrm{v} / \mathrm{v})$ was used in the experiment.

The susceptibility of L. monocytogenes to OLE and/or PAA was assessed by the disk diffusion method on agar, as recommended by the National Committee for Clinical Laboratory Standards [14], with minor modifications, as follows: The bacterial working suspension was spread on Petri dishes containing Tryptic Soy Agar (TSA, Sigma-Aldrich, Saint Louis, MO). After, $6 \mathrm{~mm}$ discs filter papers previously sterilized were soaked in individual solutions containing OLE $(5.0 \mathrm{mg} / \mathrm{mL})$, PAA $(2.0 \%, \mathrm{v} / \mathrm{v})$ or OLE + PAA $(5.0 \mathrm{mg} / \mathrm{mL}$, and $2.0 \%$, respectively) for $1 \mathrm{~min}$., and placed in the centre of the prepared Petri plates. Plates were incubated at $37^{\circ} \mathrm{C}$ for 48 hours. The diameters of inhibitory zones (IZ) were measured with a caliper rule, and results were interpreted as follows [14]: resistant (R), when no inhibition zone was found beyond the disk diameter $(6 \mathrm{~mm})$, intermediate $(\mathrm{I})$, with $\mathrm{IZ}=6.1$ to $10 \mathrm{~mm}$, or sensitive (S), with $\mathrm{IZ}>10 \mathrm{~mm}$.

The procedures for determination of OLE and/or PAA efficiency on L. monocytogenes biofilms in stainless steel were based on two protocols $[15,16]$. Initially, $5 \mathrm{~mL} \mathrm{BHI}$ broth and $15 \mu \mathrm{L}$ of the stock suspension were placed in test tubes and incubated at $37^{\circ} \mathrm{C} / 24 \mathrm{~h}$. After, the concentration of bacterial cells was adjusted with BHI until reaching 0.5 in the MacFarland scale (approximately $10^{8}$ cells $/ \mathrm{mL}$ ). Stainless steel square coupons $(1 \mathrm{x} 1 \mathrm{~cm})$, previously cleaned by soaking in acetone and autoclaved at $121^{\circ} \mathrm{C}$ for $15 \mathrm{~min}$, were placed at the bottom of the test tubes containing the $L$. monocytogenes culture in BHI. The tubes were incubated at $37^{\circ} \mathrm{C}$ for $48 \mathrm{~h}$ without stirring, to allow the growth of the biofilm biomass on the stainless steel coupons. After incubation, the tubes were emptied and the stainless steel coupons were treated with individual solutions $(2 \mathrm{~mL})$ containing OLE $(5.0 \mathrm{mg} / \mathrm{mL})$, PAA $(2.0 \%$, v/v) or OLE + PAA $(5.0$ $\mathrm{mg} / \mathrm{mL}$, and $2.0 \%, \mathrm{v} / \mathrm{v}$, respectively) for $1 \mathrm{~min}$. Two $\mathrm{mL}$ of sodium thiosulfate was added to the tubes and allowed to set for $5 \mathrm{~min}$. to stop reaction. After treatment, the stainless steel coupons were removed from the tubes with sterile forceps, washed with phosphate buffered saline three times to remove the non-adhered cells, allowed to dry at room temperature, and finally placed into NUNC wells (Lab-Tek Chamber Slide System, USA). The viability of surface-bound bacteria in the biofilm layer after treatment with OLE and/or PAA was examined by pipetting $30 \mu \mathrm{L}$ of LIVE/DEAD ${ }^{\circledR}$ Baclight kit (Molecular Probes, OR) containing Syto 9 and propidium iodide dyes directly on the stainless steel coupons. After 10 min. incubation, the coupons were examined in a TCS SP5 ${ }^{\circledR}$ confocal laser scanning microscope (Leica Mycrosystems, Germany) for visualization of biofilms. An argon laser (488 nm, fluorescent green) was used to observe cells stained with Syto 9, and a helium laser (543 nm, fluorescent red) was used to observe cells stained with propidium iodide. The images were processed using LAS AF ${ }^{\circledR}$ software (Leica Microsystems, Germany).

\section{RESULTS AND DISCUSSION}

Table 1 presents the results for susceptibility of L. monocytogenes ATCC 7644 to OLE and PAA, alone or in combination, obtained in the disk diffusion method. Disk diffusion method is a semi-quantitative method used in many studies using natural oils to obtain reliable results of microbial activities. Due to their hydrophobic nature, this feature prevents the uniform diffusion of such substances by the agar-containing medium [17]. The L. monocytogenes strain 
tested (ATCC 7644) was not susceptible to OLE (IZ = $6.0 \mathrm{~mm}$ ), although it was sensitive to PAA+OLE (IZ = $14 \mathrm{~mm}$ ). Tataridou et al. [18] observed that olive homogenates reduced 6-7 log cycles of $L$. monocytogenes Scott A cells after $8-10 \mathrm{~h}$ treatment at $30^{\circ} \mathrm{C}$. Medina et al. [10] also reported antimicrobial activities of olive oils against $L$. monocytogenes CECT 4031 strain. However, results of our study and the previously mentioned works are not fully comparable because they used olive extracts that may contain other phenolic active compounds, instead of the isolated OLE. Moreover, the different antimicrobial effects observed among studies may also be associated with the variability of susceptibilities among different $L$. monocytogenes strains, since the stress response of bacteria is strain specific [19]. Importantly, the strain tested in the present study is a strong biofilm-producer [13], and had intermediate susceptibility to PAA treatment $(\mathrm{IZ}=8.7 \pm 1.2)$, which is a chemical sanitizer commonly used worldwide. This fact may contribute for the ability of L. monocytogenes to survive in biofilms formed on equipments and instruments in food industries [20]. Thus the entrance of this pathogen in food processing areas does not only involve an immediate risk to food safety, but also the risk of a long-term persistence unless appropriate measurements are applied to eliminate the risk [21].

Table 1. Susceptibility of L. monocytogenes ATCC 7644 to oleuropein (OLE) and peracetic acid (PAA), alone or in combination, in the disk diffusion method.

\begin{tabular}{|c|c|c|}
\hline Solution & Diameter of inhibition zone (mm) $)^{\mathbf{1}}$ & Classification $^{\mathbf{2}}$ \\
\hline Control (sterilized water) & $6.0 \pm 0.00$ & Resistant $^{\text {Resistant }}$ \\
\hline OLE $(5.0 \mathrm{mg} / \mathrm{mL})$ & $6.0 \pm 0.00$ & Intermediate \\
\hline PAA $(2.0 \%, \mathrm{v} / \mathrm{v})$ & $8.7 \pm 1.2$ & Sensitive \\
\hline PAA $(2.0 \%, \mathrm{v} / \mathrm{v})+$ OLE $(5.0 \mathrm{mg} / \mathrm{mL})$ & $14.0 \pm 0.0$ & . \\
\hline
\end{tabular}

${ }^{1}$ Results are reported as mean \pm standard deviation of triplicate assays. ${ }^{2}$ Resistant: inhibition zone (IZ) $=6 \mathrm{~mm}$; Intermediate: $\mathrm{IZ}=7$ to $10 \mathrm{~mm}$; Sensitive: $\mathrm{IZ}>10 \mathrm{~mm}$, according.

The combination of OLE and PAA increased the individual IZ value for PAA, indicating an additive effect of OLE. The comparison of results obtained in this study with others is limited as there is no previous report on the inhibitory effect of OLE in combination with other sanitizers against L. monocytogenes. Although the mechanisms of antimicrobial activity of OLE are not completely understood, previous studies have shown that OLE and other compounds in olive oil interact with phosphatidylglycerol at the surface of the bacterial cell wall [22], and cause changes in the cytoplasmic membrane which could lead to the disruption of the cell envelope [18]. Therefore those effects may have contributed to the greater antimicrobial activity of PAA combined with OLE.

Results of the confocal laser scanning microscopy for evaluation of biofilms on stainless steel coupons treated with OLE and/or PAA are presented in Fig (1). OLE alone in contact with biofilms had lower bactericidal activity on the biofilms (Fig. 1-A), when compared with PAA (Fig. 1-B). However, the application of OLE in combination with PAA (Fig. 1-C) resulted in greater inactivation of the biofilms. Previous studies [23, 24] indicated that PAA had higher effectiveness against $L$. monocytogenes, when compared with other chemical sanitizer, although mature biofilms of $L$. monocytogenes have been reported as low susceptibility to PAA [7,25]. This fact may be associated to the lipophilic nature of EPS produced by the biofilms, which hinders the penetration of the sanitizer. Stopforth et al. [23] reported that PAA was effective against biofilms formed by $L$. monocytogenes, being also useful to control biofilms containing food residues. However, in the present study PAA was not able to inactivate completely the biofilm formed by L. monocytogenes ATCC 7644 on stainless steel, which corroborate the strain variability to bacterial stress response [19]. A possible explanation for this low susceptibility to PAA is that EPS acts as a physical barrier, which reduces the penetration of the antimicrobial agent [26].

The difficulty in removing biofilms may be associated with its wide phenotypic heterogeneity, with populations of cells expressing different levels of susceptibility, hence requiring the combined use of substances that break the EPS structure and facilitate the entry of disinfectant to kill the microorganisms, or substances that induce the dispersal of biofilm cells $[27,28]$. In this context, the antimicrobial activity of OLE could be associated to its surface-active properties, which may change the permeability of the cell membrane [29]. Hence the polarity of the molecules (OLE and EPS) could favor the absorption of OLE and facilitate the penetration of PAA in the biofilm matrix, resulting in an additive effect of PPA against the biofilms of $L$. monocytogenes. 

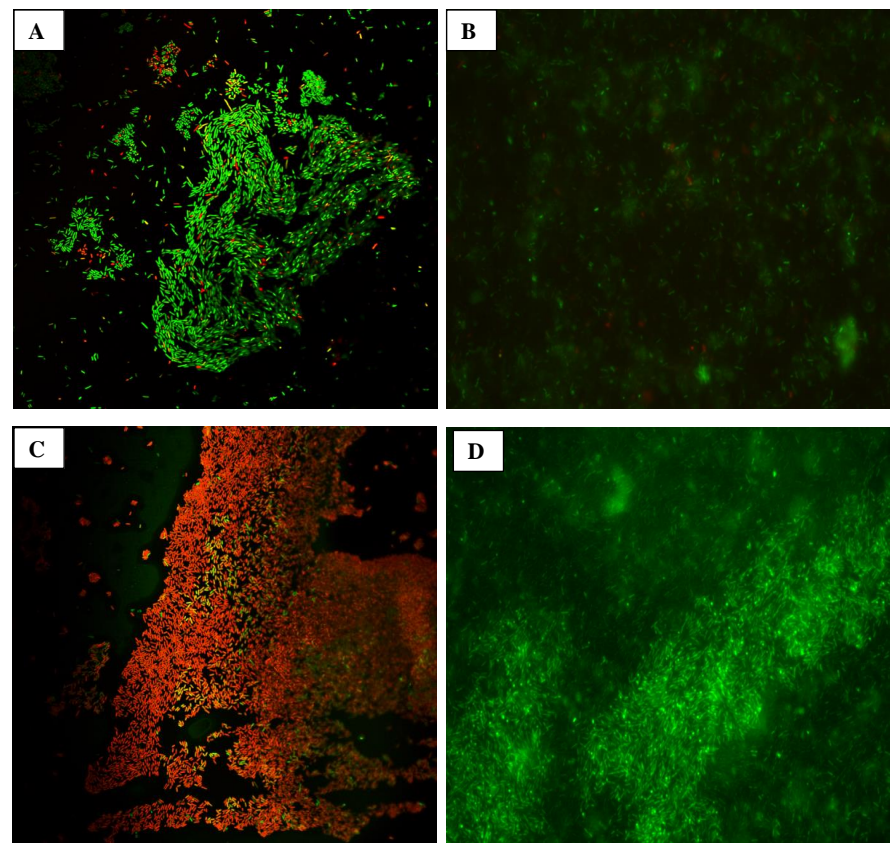

Fig. (1). Confocal laser scanning micrographs of biofilms of Listeria monocytogenes ATCC 7644 formed on stainless steel surfaces for 48 hours at $37^{\circ} \mathrm{C}$, after treatment with peracetic acid $(2.0 \%, \mathrm{v} / \mathrm{v})(\mathbf{A})$, oleuropein $(5.0 \mathrm{mg} / \mathrm{mL})(\mathbf{B})$ or peracetic acid + oleuropein $(5.0 \mathrm{mg} / \mathrm{mL}$ and $2.0 \%, \mathrm{v} / \mathrm{v}$, respectively) $(\mathbf{C})$. Untreated (control) L. monocytogenes biofilm is shown in (D). Cells were treated with sanitizer for 1 minute, neutralized and then were stained with bacterial viability kit LIVE/DEAD (Molecular Probes, OR). Viable cells were stained fluorescent green (Syto 9) and non-viable cells were stained red fluorescence (propidium of iodide). Magnification: $630 \mathrm{X}$.

\section{CONCLUSION}

Results of this study indicate a potential for using OLE to enhance the bactericidal effect of PAA against $L$. monocytogenes biofilms, although further studies are necessary to understand the mechanisms of action of OLE in combination with others commercial chemical sanitizers.

\section{CONFLICT OF INTEREST}

The authors confirm that this article content has no conflict of interest.

\section{ACKNOWLEDGEMENTS}

The authors thank the Conselho Nacional de Desenvolvimento Científico e Tecnológico (CNPq, Grant 309348/2013-7), for the financial support. They are also grateful to M.Sc. Vanessa M. de Souza (FCFRP/USP) for her technical assistance during sample preparation for confocal laser scanning microscopy, and to Ms. Elizabete R. Milani (FMRP/SP) for running the microscopy analyses.

\section{REFERENCES}

[1] Gandhi, M.; Chikindas, M.L. Listeria: A foodborne pathogen that knows how to survive. Int. J. Food Microbiol., 2007, 113(1), 1-15. [http://dx.doi.org/10.1016/j.ijfoodmicro.2006.07.008] [PMID: 17010463]

[2] Chae, M.S.; Schraft, H. Comparative evaluation of adhesion and biofilm formation of different Listeria monocytogenes strains. Int. J. Food Microbiol., 2000, 62(1-2), 103-111.

[http://dx.doi.org/10.1016/S0168-1605(00)00406-2] [PMID: 11139010]

[3] Renier, S.; Hébraud, M.; Desvaux, M. Molecular biology of surface colonization by Listeria monocytogenes: an additional facet of an opportunistic Gram-positive foodborne pathogen. Environ. Microbiol., 2011, 13(4), 835-850.

[http://dx.doi.org/10.1111/j.1462-2920.2010.02378.x] [PMID: 21087384]

[4] Carpentier, B.; Chassaing, D. Interactions in biofilms between Listeria monocytogenes and resident microorganisms from food industry premises. Int. J. Food Microbiol., 2004, 97(2), 111-122.

[http://dx.doi.org/10.1016/j.ijfoodmicro.2004.03.031] [PMID: 15541798]

[5] McDonnell, G.; Russell, A.D. Antiseptics and disinfectants: activity, action, and resistance. Clin. Microbiol. Rev., 1999, 12(1), 147-179. [PMID: 9880479] 
[6] van der Veen, S.; Abee, T. Importance of SigB for Listeria monocytogenes static and continuous-flow biofilm formation and disinfectant resistance. Appl. Environ. Microbiol., 2010, 76(23), 7854-7860. [http://dx.doi.org/10.1128/AEM.01519-10] [PMID: 20889779]

[7] Fatemi, P.; Frank, J.F. Inactivation of Listeria monocytogenes/Pseudomonas biofilms by peracid sanitizers. J. Food Prot., 1999, 62(7), 761-765. [PMID: 10419269]

[8] Benavente-Garcia, O.; Castillo, J.; Lorente, J. Antioxidant activity of phenolics extracted from Olea europaea leaves. Food Chem., 2000, 68, 457-462.

[http://dx.doi.org/10.1016/S0308-8146(99)00221-6]

[9] Tripoli, E.; Giammanco, M.; Tabacchi, G.; Di Majo, D.; Giammanco, S.; La Guardia, M. The phenolic compounds of olive oil: structure, biological activity and beneficial effects on human health. Nutr. Res. Rev., 2005, 18(1), 98-112. [http://dx.doi.org/10.1079/NRR200495] [PMID: 19079898]

[10] Medina, E.; de Castro, A.; Romero, C.; Brenes, M. Comparison of the concentrations of phenolic compounds in olive oils and other plant oils: correlation with antimicrobial activity. J. Agric. Food Chem., 2006, 54(14), 4954-4961. [http://dx.doi.org/10.1021/jf0602267] [PMID: 16819902]

[11] Laincer, F.; Laribi, R.; Tamendjari, A. Olive oils from Algeria: Phenolic compounds, antioxidant and antibacterial activities. Grasas Aceites, 2014, 65(1), e001.

[http://dx.doi.org/10.3989/gya.035713]

[12] Bisignano, G.; Tomaino, A.; Lo Cascio, R.; Crisafi, G.; Uccella, N.; Saija, A. On the in-vitro antimicrobial activity of oleuropein and hydroxytyrosol. J. Pharm. Pharmacol., 1999, 51(8), 971-974. [http://dx.doi.org/10.1211/0022357991773258] [PMID: 10504039]

[13] Longhi, C.; Scoarughi, G.L.; Poggiali, F.; Cellini, A.; Carpentieri, A.; Seganti, L.; Pucci, P.; Amoresano, A.; Cocconcelli, P.S.; Artini, M.; Costerton, J.W.; Selan, L. Protease treatment affects both invasion ability and biofilm formation in Listeria monocytogenes. Microb. Pathog., 2008, 45(1), 45-52. [http://dx.doi.org/10.1016/j.micpath.2008.01.007] [PMID: 18479885]

[14] National Committee for Clinical Laboratory Standards. Methods for Dilution Antimicrobial Susceptibility Test for Bacteria That Grow Aerobically, $6^{\text {th }}$ ed.; Wayne, PA, 2003, 23, p. 81. (M7-A6).

[15] Shanks, R.M.; Donegan, N.P.; Graber, M.L.; Buckingham, S.E.; Zegans, M.E.; Cheung, A.L.; O’Toole, G.A. Heparin stimulates Staphylococcus aureus biofilm formation. Infect. Immun., 2005, 73(8), 4596-4606. [http://dx.doi.org/10.1128/IAI.73.8.4596-4606.2005] [PMID: 16040971]

[16] Chandra, J.; Mukherjee, P.K.; Ghannoum, M.A. In vitro growth and analysis of Candida biofilms Nat. Protoc., 2008, 3(12), $1909-1924$. [http://dx.doi.org/10.1038/nprot.2008.192] [PMID: 19180075]

[17] Bona, E.A.; Pinto, F.G.; Fruet, T.K. Comparison of methods for evaluation of antimicrobial activity and determination of minimum inhibitory concentration (MIC) of aqueous and ethanol plant extracts. Arq. Inst. Biol. (Sao Paulo), 2014, 81(3), 218-222. [http://dx.doi.org/10.1590/1808-1657001192012]

[18] Tataridou, M.; Kotzekidou, P. Fermentation of table olives by oleuropeinolytic starter culture in reduced salt brines and inactivation of Escherichia coli $\mathrm{O} 157: \mathrm{H} 7$ and Listeria monocytogenes. Int. J. Food Microbiol., 2015, 208, 122-130. [http://dx.doi.org/10.1016/j.ijfoodmicro.2015.06.001] [PMID: 26065729]

[19] Doyle, M.E.; Mazzotta, A.S.; Wang, T.; Wiseman, D.W.; Scott, V.N. Heat resistance of Listeria monocytogenes. J. Food Prot., 2001, 64(3), 410-429. [PMID: 11252490]

[20] Ratti, R.P.; Gomes, B.C.; Martinez, R.C. Elongated cells of Listeria monocytogenes in biofilms in the presence of sucrose and bacteriocinproducing Leuconostoc mesenteroides A11. Food Sci. Technol. (Campinas.), 2010, 30(4), 1011-1016. [http://dx.doi.org/10.1590/S0101-20612010000400027]

[21] Vásquez-Sánchez, D.; Cabo, M.L.; Ibusquiza, P.S. Biofilm-forming ability and resistance to industrial disinfectants of Staphylococcus aureus isolated from fishery products. Food Control., 2014, 39, 8-16. [http://dx.doi.org/10.1016/j.foodcont.2013.09.029]

[22] Casas-Sanchez, J.; Alsina, M.A.; Herrlein, M.K.; Mestres, C. Interaction between the antibacterial compound, oleuropein, and model membranes. Colloid Polym. Sci., 2007, 285, 1351-1360. [http://dx.doi.org/10.1007/s00396-007-1693-x]

[23] Stopforth, J.D.; Samelis, J.; Sofos, J.N.; Kendall, P.A.; Smith, G.C. Biofilm formation by acid-adapted and nonadapted Listeria monocytogenes in fresh beef decontamination washings and its subsequent inactivation with sanitizers. J. Food Prot., 2002, 65(11), $1717-1727$. [PMID: 12430692]

[24] Cruz, C.D.; Fletcher, G.C. Assessing manufacturers recommended concentrations of commercial sanitizers on inactivation of Listeria monocytogenes. Food Control., 2012, 26, 194-199. [http://dx.doi.org/10.1016/j.foodcont.2012.01.041] 
[25] Somers, E.B.; Wong, A.C. Efficacy of two cleaning and sanitizing combinations on Listeria monocytogenes biofilms formed at low temperature on a variety of materials in the presence of ready-to-eat meat residue. J. Food Prot., 2004, 67(10), 2218-2229. [PMID: 15508633]

[26] Chmielewski, R.A.; Frank, J.F. Biofilm formation and control in food processing facilities. Compr. Rev. Food Sci. F., 2003, 2, 22-31. [http://dx.doi.org/10.1111/j.1541-4337.2003.tb00012.x]

[27] Härkönen, P.; Solo, S.; Mattila-Sandholm, T.; Wirtanen, G. Development of a simple in vitro test system for the disinfection of bacterial biofilm. Water Sci. Technol., 1999, 39(7), 219-225. [http://dx.doi.org/10.1016/S0273-1223(99)00171-7]

[28] Stewart, P.S.; Franklin, M.J. Physiological heterogeneity in biofilms. Nat. Rev. Microbiol., 2008, 6(3), 199-210. [http://dx.doi.org/10.1038/nrmicro1838] [PMID: 18264116]

[29] Korukluoglu, M.; Sahan, Y.; Yigit, A. Antibacterial activity and chemical constitutions of Olea Europaea L. leaf extracts. J. Food Process. Preserv., 2010, 34, 383-396. [http://dx.doi.org/10.1111/j.1745-4549.2008.00318.x]

Received: July 26, 2015

Revised: December 3, 2015

Accepted: December 24, 2015

(C) Dominciano et al.; Licensee Bentham Open

This is an open access article licensed under the terms of the Creative Commons Attribution-Non-Commercial 4.0 International Public License (CC BY-NC 4.0) (https://creativecommons.org/licenses/by-nc/4.0/legalcode), which permits unrestricted, non-commercial use, distribution and reproduction in any medium, provided the work is properly cited 